\title{
ANALISIS PUTUSAN KEPAILITAN MAHKAMAH AGUNG NOMOR 769 K/PDT.SUS-PAILIT/2016 MENGENAI PEMBERESAN HARTA PAILIT (BOEDEL PAILIT)
}

\author{
Selly Virginia \\ ( Mahasiswa Program S1 Fakultas Hukum Universitas Tarumanagara) \\ (E-mail : sellyvirginia10@gmail.com)
}

\section{Dr. F.X Suyud Margono, S.H., M.Hum.}

(Corresponding Author)

(Dosen Fakultas Hukum Universitas Tarumanagara. Meraih Sarjana Hukum pada Fakultas Hukum Universitas Atmajaya, Magister Hukum pada Universitas Tarumanagara, Program Pascasarjana, Doktor (Dr.) pada Fakultas Hukum Universitas Katolik Parahyangan)

(E-mail: suyudmargono@gmail.com)

\begin{abstract}
Abstrak
The progress of the economy in Indonesia is currently experiencing very rapid development, giving rise to very tight competition between business actors. In the business world the need for funds is a basic necessity that must be met by businesses to maintain and support the continuity of their business activities, so that to overcome the problem of capital needs, loan capital in the form of accounts payable is a solution that is often taken by businesses. Of course business people need funds or capital to strengthen their position in the economic sphere and intense competition in this era of globalization. Funds or capital needed by business people to run their businesses are obtained from debt facilities (loans or loans) obtained through individuals or financial institutions, which are used to increase their business capital both in the form of short-term, medium-term and long-term debt. This paper identifies one problem, namely whether someone / person is not declared bankrupt can be made bankrupt? (Case Study of Decision of the Supreme Court Number $769 \mathrm{~K} /$ Pdt.Sus-Pailit /2016). The method used in this study is a type of analytical descriptive legal research and uses primary and secondary legal materials. The results of the study show that the property of a person or person referred to herein is the property of the Director (along with 2 partners) who at the beginning had made an agreement in order to make the asset in the name of The Hwie Gwan a guarantee by both parties.
\end{abstract}

Keywords : Bankruptcy, Bankrupt Estate, Corporate. 


\section{PENDAHULUAN}

\section{A. Latar Belakang}

Kemajuan perekonomian antar pelaku usaha di Indonesia pada saat ini sangat ketat dikarenakan perkembangan yang sangat pesat. Pelaku usaha dalam menunjang dan mempertahankan kelangsungan kegiatan usahanya di dunia bisnis memerlukan kebutuhan pokok yaitu dana yang harus dipenuhi, dalam mengatasi persoalan tersebut maka para pelaku usaha menemukan solusi yaitu dengan menempuh cara melakukan pinjaman modal dalam bentuk utang piutang. Para pelaku usaha yang mendirikan badan usaha berupa perusahaan tentu membutuhkan dana atau modal untuk mengokohkan posisinya dalam lingkup perekonomian dan persaingan yang ketat di era globalisasi ini. Dana atau modal yang dibutuhkan oleh para pelaku usaha untuk menjalankan usahanya di dapatkan dari fasilitas utang (pinjaman atau kredit) yang diperoleh melalui perorangan maupun lembaga keuangan, yang digunakan untuk menambah modal usahanya baik utang dalam bentuk jangka pendek, jangka mengengah maupun jangka panjang.

Pihak penting di dalam utang piutang yaitu terdapat pihak yang berhutang selaku debitor dan pihak yang memiliki piutang atau pihak yang memberikan utang selaku kreditor. Debitor selaku pihak yang memerlukan dana akan melakukan pinjaman berupa utang kepada kreditor, seringkali guna untuk memenuhi kebutuhan dana tersebut, debitor melakukan pinjaman kepada lebih dari satu kreditor. Kemudian sering kali persoalan yang timbul di kemudian hari adalah pada saat waktu yang telah ditentukan atau jatuh tempo dan debitor tidak dapat mengembalikan pinjaman terhadap kreditor ataupun tidak memiliki kemauan untuk mengembalikan pinjaman berupa utang beserta bunga yang telah ditentukan kepada salah satu atau beberapa kreditornya, jelas hal tersebut merugikan kreditor yang telah memberikan utang kepada debitor tersebut.

Jika dalam batas waktu yang telah ditentukan, Debitor belum bisa melunasi pinjamannya maka Debitor dapat mengajukan permohonan Penundaan Kewajiban Pembayaran Utang (selanjutnya disebut dengan 
PKPU), keadaan tidak mampu membayar lazimnya disebabkan suatu kondisi kesulitan keuangan (financial distress) dari usaha Debitor yang mengalami kemunduran. ${ }^{1)}$ PKPU dilakukan sebagai upaya untuk mencegah terjadinya pailit. PKPU diatur dengan jelas dan juga terperinci dalam Undang-Undang Nomor 37 Tahun 2004 tentang Kepailitan dan Penundaan Kewajiban Pembayaran Utang. PKPU adalah suatu masa yang diberikan oleh Undang-Undang melalui putusan hakim niaga dimana pada masa tersebut para pihak yaitu Kreditor dan juga Debitor diberikan kesempatan untuk bermusyawarah dan bermufakat tentang bagaimana cara-cara melakukan pembayaran utang dengan memberikan rencana pembayaran seluruh atau sebagian dari utangnya tersebut. ${ }^{2)}$ PKPU bisa dimohonkan oleh Debitor atau Kreditor yang mengalami permasalahan dalam hal utangpiutang. Ketentuan mengenai Kreditor dapat mengajukan PKPU merupakan ketentuan baru dalam UUK PKPU. ${ }^{3)}$

Tujuan dari dilaksanakannya PKPU adalah perdamaian. Perdamaian tersebut berupa perjanjian di antara Debitor dan satu atau beberapa Kreditornya, dimana Debitor menawarkan diri untuk melakukan pembayaran atas utangnya dengan syarat bahwa setelah si Debitor telah melakukan pembayaran utangnya baik sebagian maupun seluruhnya, maka Debitor telah melaksanakan perjanjian perdamaian, sehingga Debitor tidak mempunyai utang kembali. ${ }^{4)}$ Sesuai dengan ketentuan yang dimuat dalam UUK PKPU yang menyatakan bahwa Debitor memiliki hak untuk menawarkan suatu perdamaian kepada semua kreditur. ${ }^{5)}$

\footnotetext{
1) Sutan Remy Sjahdeini, Hukum Kepailitan: Memahami Undang-Undang No.37 Tahun 2004 tentang kepailitan, (Jakarta: Pustaka Utama Grafiti, 2010), hal.2.

2) Munir Fuady, Hukum Kontrak: Teori dan Teknik Penyusunan Kontrak, (Jakarta: Sinar Grafika, 2003), hal.98.

3) M. Hadi Subhan, Hukum Kepailitan "Prinsip, Norma, dan Praktik di Peradilan", (Jakarta: Kencana, 2008), hal.147.

4) Rahayu Hartini, Penyelesaian Sengketa Kepailitan di Indonesia, Dualisme Kewenangan Pengadilan Niaga \& Lembaga Arbitrase, Cetakan Ke-1, (Jakarta: Kencana Prenada Media Group, 2009), hal.100.

5) Pasal 222 Undang-Undang Nomor 37 Tahun 2004 tentang kepailitan dan Penundaan Kewajiban Pembayaran Utang.
} 
Terdapat permasalahan yang seringkali harus dihadapi oleh para kreditor di dalam kepailitan, terutama kreditor konkuren atau kreditor biasa (unsecured creditor) adalah untuk mendapatkan pelunasan piutangnya terhadap debitor yang telah dinyatakan pailit, disebabkan kareta adanya itikad tidak baik dari debitor untuk mengalihkan aset harta kekayaan yang dimilikinya atau segala upaya debitor pailit yang dilakukan untuk menghambat pengurusan dan pemberesan harta kekayaan pailit (boedel pailit) oleh kurator. Permasalahan lain yang mungkin dihadapi adalah adanya itikad buruk atau ketidakmampuan dari hakim pengawas dan kurator dalam melakukan pengurusan dan pemberesan harta kekayaan pailit (boedel pailit), kemudian apabila harta kekayaan milik debitor pailit tidak cukup untuk melunasi segala utang-utangnya kepada para kreditornya, terlebih apabila kreditor konkuren tersebut dihadapkan dengan situasi adanya kreditor pemegang hak jaminan kebendaan yang juga memiliki piutang kepada debitor, mengingat menurut Pasal 1132 dan 1133 Kitab Undangundang Hukum Perdata para kreditor pemegang hak jaminan kebendaan (secured creditor) memiliki hak untuk mendapatkan pelunasan piutang yang dimilikinya dari harta kekayaan debitor pailit secara terlebih dahulu daripada kreditor konkuren (unsecured creditor).

Dalam perkembangannya PT. Mega Graha International telah dinyatakan Pailit dengan segala akibat hukumnya berdasarkan Putusan Pengadilan Niaga pada Pengadilan Negeri Jakarta Pusat Nomor 16/Pdt-SusPailit/2015/PN.Niaga.Jkt.Pst., tertanggal 23 Juli 2015. Dengan Pailitnya PT. Mega Graha International, maka PT. Mega Graha International terbukti telah cidera janji/wanprestasi terhadap PT. Bank OCBC NISP Tbk dan konsekuensi hukumnya PT. Bank OCBC NISP Tbk sebagai Pemegang Hak Tanggungan berhak untuk segera melakukan Lelang Eksekusi Hak Tanggungan terhadap Sertifikat Hak Guna Bangunan Nomor 3505/Meruya Utara, terdaftar atas nama The Hwie Gwan.

PT. Bank OCBC NISP Tbk telah mengajukan Permohonan Lelang Eksekusi Hak Tanggungan atas Sertifikat Hak Guna Bangunan Nomor 
3505/Meruya Utara tersebut di Kantor Pelayanan Kekayaan Negara dan Lelang (KPKNL) Jakarta IV pada tanggal 15 September 2015, namun ternyata terhadap Permohonan Lelang tersebut KPKNL Jakarta IV menyatakan tidak dapat melanjutkan permohonan lelang eksekusi Hak Tanggungan atas Sertifikat Hak Guna Bangunan Nomor 3505/Meruya Utara tersebut dengan alasan Sertifikat Hak Guna Bangunan Nomor 3505/Meruya Utara telah dimasukkan oleh Tergugat ke dalam Daftar Aset Sementara/Boedel Pailit PT. Mega Graha International dengan alasan karena biaya pembelian asset tersebut berasal dari harta kekayaan PT. Mega Graha International adalah alasan yang sangat menyesatkan dan tidak berdalil hukum.

Akibat dari hal itu PT. Bank OCBC NISP Tbk merasa dirugikan karena menganggap tindakan tersebut yang dengan secara sepihak telah memasukkan Sertifikat Hak Guna Bangunan Nomor 3505/Meruya Utara ke dalam Daftar Harta/Boedel Pailit, tertanggal 9 September 2015, padahal secara jelas dan terang benderang Sertifikat Hak Guna Bangunan Nomor 3505/Meruya Utara tersebut bukan merupakan Harta/Boedel Pailit PT. Mega Graha International. Kemudian PT. Bank OCBC NISP Tbk mengajukan permohonan kasasi kepada Pengadilan Niaga pada Pengadilan Negeri Jakarta Pusat agar dapat memberikan keadilan seadil-adilnya.

Berdasarkan uraian di atas, penulis merasa tertarik untuk mengangkat permasalahan yang timbul ke dalam suatu penulisan skripsi yang berjudul: "Analisis Putusan Kepailitan Mahkamah Agung Nomor 769 K/Pdt.SusPailit/2016 Mengenai Pemberesan Harta Pailit/Boedel Pailit"

\section{B. Perumusan Masalah}

Berdasarkan latar belakang diatas, Penulis menemukan rumusan masalah yang dapat diangkat dalam penelitian ini:

1. Apakah Harta Seseorang/Pribadi yang Tidak Dinyatakan Pailit Dapat Dijadikan Boedel Pailit? (Studi Kasus Putusan Mahkamah Agung Nomor 769 K/Pdt.Sus-Pailit/2016) 


\section{Metode Penelitian}

Dalam penelitian ini, penulis menggukanan metode penelitian yaitu penelitian deskriptif analitis. Maksud dari penelitian ini adalah untuk memperolah gambaran yang lengkap dan secara jelas tentang permasalahan kepailitan yang digunakan dapat dikaitkan dengan ketentuan-ketentuan atau peraturan-peraturan hukum yang berlaku, sehingga pada akhirnya dapat diperoleh suatu kesimpulan. Analisis data dalam penelitian ini bersifat induktif, yaitu "pengembangan konsep yang didasarkan atas data yang ada, mengikuti desain penelitian yang fleksibel sesuai dengan konteksnya. Desain tersebut tidak kaku sehingga memberi peluang kepada peneliti untuk menyesuaikan diri dengan konteks yang ada dilapangan". ${ }^{21)}$

\section{Pembahasan}

Sebelum memasuki kedalam permasalahan yang ingin diangkat untuk dianalisis, patutlah mengerti terlebih dahulu mengenai Pailit dan Boedel Pailit, Pailit dan Boedel Pailit merupakan bagian dari sub sistem hukum Kepailitan. Hukum kepailitan sendiri merupakan bagian dari sub sistem Hukum. Pada tahun 2015, PT. Mega Graha International mengajukan permohonan pemberian fasilitas kredit/utang kepada PT. Bank OCBC NISP Tbk yang kemudian dituangkan kedalam:

a. Akta Perjanjian Penyediaan Fasilitas Kredit, Nomor 32, tertanggal 16 Februari 2007, yang dibuat dihadapan Mellyani Noor Shandra, Sarjana Hukum, Notaris di Jakarta Barat (Bukti P-1).

b. Perjanjian Demand Loan Nomor 03949-0-01, tertanggal 16 Februari 2007, yang dibuat dibawah tangan bermeterai cukup (Bukti P-2).

c. Perjanjian Fasilitas Post Import Financing (PIF) Nomor 004 /CO /LC

d. Akta Perubahan Atas Perjanjian Fasilitas Kepada PT. Mega Graha International, Nomor 23, tertanggal 10 Maret 2015, yang dibuat dihadapan Teddy Anwar, Sarjana Hukum, Notaris di Jakarta Pusat.

21) Beni Ahmad Soebani, "Metode Penelitian Hukum", Cetakan ke-I, (Bandung: Pustaka Setia, 2009), hal.103. 
Bahwa untuk menjamin terlaksananya pembayaran kembali beberapa Fasilitas Kredit/Utang yang telah dikucurkan oleh PT. Bank OCBC NISP Tbk kepada PT. Mega Graha International, maka selanjutnya PT. Mega Graha International telah memberikan beberapa jaminan kepada PT. Bank OCBC NISP Tbk, yang antara lain berupa 1 (satu) bidang tanah berikut bangunan serta segala sesuatu yang berdiri dan melekat diatas tanah tersebut, berdasarkan Sertifikat Hak Guna Bangunan (SHGB) Nomor 3505/Meruya Utara, berakhirnya Hak Guna Bangunan pada tanggal 21 Januari 2033, terdaftar atas nama The Hwie Gwan, luas tanah $1.446 \mathrm{~m}^{2}$. Gambar Situasi Nomor 6258/1992 tertanggal 9 Oktober 1992, yang diterbitkan oleh Kepala Kantor Pertanahan Kotamadya Jakarta Barat pada tanggal 22 Januari 1993, setempat dikenal umum dengan Jalan Raya Meruya Utara, Nomor 15, RT 001, RW 005, Kelurahan Meruya Utara, Kecamatan Kembangan, Kotamadya Jakarta Barat, Provinsi DKI Jakarta.

Dalam perkembangannya PT. Mega Graha International telah dinyatakan Pailit dengan segala akibat hukumnya berdasarkan Putusan Pengadilan Niaga pada Pengadilan Negeri Jakarta Pusat Nomor 16/Pdt-SusPailit/2015/PN.Niaga.Jkt.Pst., tertanggal 23 Juli 2015. Dengan Pailitnya PT. Mega Graha International, maka PT. Mega Graha International terbukti telah cidera janji/wanprestasi terhadap PT. Bank OCBC NISP Tbk dan konsekuensi hukumnya PT. Bank OCBC NISP Tbk sebagai Pemegang Hak Tanggungan berhak untuk segera melakukan Lelang Eksekusi Hak Tanggungan terhadap Sertifikat Hak Guna Bangunan Nomor 3505/Meruya Utara, terdaftar atas nama The Hwie Gwan.

PT. Bank OCBC NISP Tbk telah mengajukan Permohonan Lelang Eksekusi Hak Tanggungan atas Sertifikat Hak Guna Bangunan Nomor 3505/Meruya Utara tersebut di Kantor Pelayanan Kekayaan Negara dan Lelang (KPKNL) Jakarta IV pada tanggal 15 September 2015, namun ternyata terhadap Permohonan Lelang tersebut KPKNL Jakarta IV menyatakan tidak dapat melanjutkan permohonan lelang eksekusi Hak Tanggungan atas Sertifikat Hak Guna Bangunan Nomor 3505/Meruya Utara tersebut dengan alasan Sertifikat Hak Guna Bangunan Nomor 3505/Meruya Utara telah dimasukkan oleh Tergugat ke 
dalam Daftar Aset Sementara/Boedel Pailit PT. Mega Graha International dengan alasan karena biaya pembelian asset tersebut berasal dari harta kekayaan PT. Mega Graha International adalah alasan yang sangat menyesatkan dan tidak berdalil hukum.

Akibat dari hal itu PT. Bank OCBC NISP Tbk merasa dirugikan karena menganggap tindakan tersebut yang dengan secara sepihak telah memasukkan Sertifikat Hak Guna Bangunan Nomor 3505/Meruya Utara ke dalam Daftar Harta/Boedel Pailit, tertanggal 9 September 2015, padahal secara jelas dan terang benderang Sertifikat Hak Guna Bangunan Nomor 3505/Meruya Utara tersebut bukan merupakan Harta/Boedel Pailit PT. Mega Graha International. Kemudian PT. Bank OCBC NISP Tbk mengajukan permohonan kasasi kepada Pengadilan Niaga pada Pengadilan Negeri Jakarta Pusat agar dapat memberikan keadilan seadil-adilnya.

Dalam dunia praktik, tidak jarang pula terjadi ke salah pahaman yang terjadi antara Debitor dan Kreditor. Di dalam kasus ini, PT. OCBC NISP selaku Debitor menganggap PT. Mega Graha Internasional selaku Kreditor lalai, yang dimaksud lalai disini adalah PT. Mega Graha Internasional dianggap secara sepihak memasukan jaminan ke dalam harta Boedel Pailit, yang nyatanya Ronal M. Aritonang menyatakan telah ada masa waktu yang diberikan kepada PT. OCBC NISP untuk melelang jaminan tersebut, dan tidak kunjung dilelang. Pengumuman pemasukan harta Boedel Pailit tersebut juga telah diumumkan di Pengadian Negeri Jakarta Pusat.

Menurut Pasal 104 ayat 4 Undang-Undang No. 40 tahun 2007 tentang Perseroan Terbatas yang berbunyi:

“ Anggota Direksi tidak bertanggungjawab atas kepailitan Perseroan sebagaimana dimaksud pada ayat (2) apabila dapat membuktikan:

a. Kepailitan tersebut bukan karena kesalahan atau kelalaiannya;

b. Telah melakukan pengurusan dengan itikad baik, kehati-hatian, dan penuh tanggungjawab untuk kepentingan Perseroan dan sesuai dengan maksud dan tujuan Perseroan;

c. Tidak mempunyai benturan kepentingan baik langsung maupun tidak langsung atas tindakan pengurusan yang dilakukan; dan

d. Telah mengambil tindakan untuk mencegah terjadinya kepailitan." 
Dimana dapat diketahui bahwa The Hwie Gwan selaku Dikertur tidak pernah dengan secara sengaja melakukan tidakan seperti yang tertulis dalam poin a sampai dengan poin d di dalam Undang-Undang Pasal 104 ayat 4 UndangUndang No. 40 tahun 2007 tentang Perseroan Terbatas, maka dari itu apa bila terjadi kepailitan, The Hwie Gwan selaku Direktur tidak berhak bertanggung jawab atas kepailitan tersebut dan aset kepemilikan The Hwie Gwan tidak dapat dimasukan kedalam Boedel Pailit dikarenakan bukan atas nama Perseroan tersebut.

Bapak Ronal M. Aritonang berpendapat bahwa harta seseorang yang tidak pailit dapat dijadikan Boedel Pailit hal itu bersumber pada laporan keuangannya, maksudnya adalah yang menjaminkan hal tersebut adalah PT. nya dan bukan pribadinya yang menjaminkan, didalam hak tanggungan juga telah dikatakan bahwa melepaskan hak atas aset tersebut untuk menjadi jaminan PT. OCBC NISP. The Hwie Gwan selaku Direktur dan atas nama sebidang tanah beserta bangunan yang dijaminkan juga telah setuju bahwa tanah beserta bangunan yang terletak di Meruya untuk di masukan ke dalam harta Boedel Pailit. The Hwie Gwan juga secara jelas tidak mengakui tanah beserta bangunan tersebut sebagai harta pribadinya karena tanah beserta bangunannya tersebut adalah bukan milik pribadi melainkan milik gabungan dari beberapa pihak (yaitu 3 orang). Bahwa The Hwie Gwan beserta kedua pihak lainnya secara pribadi telah menandatangani aset tersebut untuk di jadikan jaminan PT. OCBC NISP, dengan menandatanganinya secara tidak langsung The Hwie Gwan sudah melepaskannya untuk dijadikan jaminan. ${ }^{52)}$

Jadi berdasarkan uraian tersebut diatas, penulis berpendapat bahwa penolakan terhadap gugutan yang diajukan oleh PT. OCBC NISP sudah betul adanya dikarenakan sudah terdapat bukti secara tertulis diantara pihak Debitur dan Kreditur bahwa The Hwie Gwan beserta 2 pihak lainnya telah melepaskan haknya dan menyerahkan tanah beserta bangunannya yang terletak di Meruya untuk dijadikan jaminan atas PT. Mega Graha Internasional.

${ }^{52)}$ Ronal M. Aritonang. Wawancara dengan Kuasa Hukum Kurator dari PT. Mega Graha Internasional, Kantor Bernard Nainggolan \& Partners , Jakarta 24 Juni 2019. 
Undang-Undang Kepailitan dan PKPU membentuk suatu peradilan khusus yang berwenang menangani perkara kepailitan, yaitu Pengadilan Niaga yang berada di lingkungan peradilan umum. Proses permohonan putusan pernyataan pailit diatur dalam Pasal 6 sampai dengan Pasal 11 UUK dan PKPU. Prosesnya dapat dijelaskan sebagai berikut:

1. Permohonan pernyataan pailit diajukan kepada Ketua Pengadilan dan panitera yang mendaftarkan permohonan pernyataan pailit pada tanggal permohonan yang bersangkutan diajukan.

2. Pemohon juga harus menyertakan berkas-berkas yang menjadi syaratsyarat pengajuan, antara lain:

a. Surat permohonan bermaterai yang ditujukan kepada Ketua Pengadilan Niaga.

b. Kartu advokat.

c. Bukti yang menunjukkan adanya perikatan (perjanjian jual-beli, hutang-piutang, putusan pengadilan, commercial paper, faktur, kuitansi, dan lain-lain.

d. Surat kuasa khusus.

e. Tanda daftar perusahaan yang dilegalisir oleh kantor perdagangan.

f. Perincian hutang yang tidak dibayar.

g. Terjemahan dalam bahasa Indonesia oleh penerjemah resmi (disumpah) jika menyangkut bahasa asing.

h. Nama dan alamat masing-masing kreditur / debitur.

Sistematika surat permohonan pernyataan pailit pada dasarnya sama dengan surat gugatan biasa, hanya saja dalam kepailitan perlu ditambahkan pengangkatan kurator dan hakim pengawas.

3. Pengadilan akan mempelajari dan menetapkan hari sidang dalam tempo paling lambat 3 hari dan sidang pemeriksaan atas permohonan pernyataan pailiy diselenggarakan dalam jangka waktu paling lambat 20 hari terhitung sejak tanggal permohonan didaftarkan. Putusan atas permohonan pernyataan pailit, menurut Pasal 8 ayat (5) UUK dan PKPU, harus 
ditetapkan dalam jangka waktu paling lambat 30 hari terhitung sejak tanggal permohonan pernyataan pailit didaftarkan.

Tata cara pengajuan permohonan pailit:

Menurut pasal 2 Undang-Undang Kepailitan, permohonan pailit dapat diajukan oleh pemohon-pemohon sebagai berikut:

a. Jika debitur adalah perusahaan bukan bank dan bukan perusahaan efek, maka yang dapat mengajukan permohonan pailit adalah:

1. Debitur

2. Seorang atau lebih kreditor, dan

3. Kejaksaan

b. Jika debitor adalah perusahaan berbentuk bank, maka yang dapat mengajukan permohonan pailit adalah Bank Indonesia

c. Jika debitur adalah perusahaan efek, maka yang dapat mengajukan permohonan pailit adalah Bapepam

d. Jika debitur adalah perseroan terbatas, maka yang harus mengajukan permohonan pailit adalah direksi perusahaan tersebut, tetapi harus berdasarkan keputusan RUPS

Syarat yuridis pengajuan Pailit:

1. Adanya hutang

2. Minimal satu hutang sudah jatuh tempo dan dapat ditagih

3. Adanya debitur

4. Adanya kreditur (lebih dari satu kreditur)

5. Permohonan pernyataan pailit

6. Pernyataan pailit oleh Pengadilan Niaga

Langkah-langkah dalam proses Kepailitan:

1. Permohonan pailit, syarat permohonan pailit telah diatur dalam UU No. 4 Tahun 1998, seperti apa yang telah ditulis di atas. 
2. Keputusan pailit berkekuatan tetap, jangka waktu permohonan pailit sampai keputusan pailit berkekuatan tetap adalah 90 hari.

3. Rapat verifikasi, adalah rapat pendaftaran utang - piutang, pada langkah ini dilakukan pendataan berupa jumlah utang dan piutang yang dimiliki oleh debitur. Verifikasi utang merupakan tahap yang paling penting dalam kepailitan karena akan ditentukan urutan pertimbangan hak dari masing masing kreditur.

4. Perdamaian, jika perdamaian diterima maka proses kepailitan berakhir, jika tidak maka akan dilanjutkan ke proses selanjutnya. Proses perdamaian selalu diupayakan dan diagendakan.

5. Homologasi akur, yaitu permintaan pengesahan oleh Pengadilan Niaga, jika proses perdamaian diterima.

6. Insolvensi, yaitu suatu keadaan di mana debitur dinyatakan benar - benar tidak mampu membayar, atau dengan kata lain harta debitur lebih sedikit jumlah dengan hutangnya.

7. Pemberesan / likuidasi, yaitu penjualan harta kekayaan debitur pailit, yang dibagikan kepada kreditur konkruen, setelah dikurangi biaya - biaya.

8. Rehabilitasi, yaitu suatu usaha pemulihan nama baik kreditur, akan tetapi dengan catatan jika proses perdamaian diterima, karena jika perdamaian ditolak maka rehabilitasi tidak ada.

9. Kepailitan berakhir.

Kemudian Pengertian Kepailitan itu sendiri menurut Undang-Undang Kepailitan dan Penundaan Kewajiban Pembayaran Utang No. 37 Tahun 2004 adalah :

"Sita umum atas semua kekayaan Debitor Pailit yang pengurusan dan pemberesannya dilakukan oleh Kurator di bawah Hakim Pengawas sebagaimana diatur dalam Undang-Undang ini (pasal 1 ayat (1)” 
Boedel pailit di dalam Undang-Undang Kepailitan tidak didefinisikan secara khusus, namun Akibat Kepailitan berdasarkan Pasal 21 Undang-Undang No. 37 tahun 2004 tentang Kepailitan dan Penundaan Pembayaran Kewajiban Utang menyatakan Kepailitan meliputi seluruh harta kekayaan debitor pada saat putusan pernyataan pailit diucapkan serta segala sesuatu yang diperoleh selama kepailitan, sehingga dapat ditarik kesimpulan Boedel pailit adalah seluruh harta kekayaan debitor baik benda bergerak maupun benda tidak bergerak yang disita oleh kurator sejak pernyataan pailit diucapkan, serta segala sesuatu yang didapat selama kepailitan, yang disita untuk kepentingan pemberesan kepailitan.

Debitur Pailit adalah PT. Mega Graha International, Debitur Pailit telah mendapatkan pinjaman dari Bank OCBC NISP, Tbk, dengan memberikan beberapa jaminan yang salah satunya adalah SHGB No. 3505/Meruya atas nama The Hwie Gwan, maka yang wajib dimasukan ke dalam daftar sementara Boedel Pailit adalah seluruh harta kekayaan milik PT. Mega Graha International, karena ada beberapa jaminan yang telah diberikan oleh Debitur Pailit, maka jaminan yang atas Nama Debitur Pailit yang dapat dimasukan ke dalam Boedel Pailit, sedangkan Jaminan SHGB No. 3505/Meruya atas nama milik The Hwie Gwan bukan merupakan bagian dari Boedel Pailit kecuali Kurator dapat membuktikan bahwa Jaminan SHGB No. 3505/Meruya a/n milik The Hwie Gwan merupakan harta yang didapatkan oleh Debitur dari harta kekekayaan Debitur.

Bahwa setalah Debitor dinyatakan Pailit oleh Putusan Pengadilan Maka berdasarkan Pasal 15 Ayat (4) Undang-Undang No. 37 tahun 2004 tentang Kepailitan dan Penundaan Pembayaran Kewajiban Utang, yang menyatakan : Dalam jangka waktu paling lambat 5 (lima) hari setelah tanggal putusan pernyataan pailit diterima oleh Kurator dan Hakim Pengawas, Kurator mengumumkan dalam Berita Negara Republik Indonesia dan paling sedikit 2 (dua) surat kabar harian yang ditetapkan oleh Hakim Pengawas, mengenai ikhtisar putusan pernyataan pailit yang memuat hal-hal sebagai berikut:

1. Nama, alamat, dan pekerjaan Debitor; 
2. Nama Hakim Pengawas;

3. Nama, alamat, dan pekerjaan Kurator;

4. Nama, alamat, dan pekerjaan anggota panitia Kreditor sementara, apabila telah ditunjuk; dan

5. Tempat dan waktu penyelenggaraan rapat pertama Kreditor.

Tujuan diumumkan melalui surat kabar agar seluruh kreditor mengetahui adanya kepailitan atas Debitor, agar mengajukan tagihan utang kepada Kurator, sehingga tidak ada alasan bagi kreditur tidak mengetahui, karena sejak diumumkan disurat kabar harian maka seluruh kreditur dianggap telah mengetahui adanya kepailitan tersebut, setelah adanya pengumuman surat kabar bertujuan agar seluruh kreditur dapat mengakses segala informasi mengenai kegiatan proses pemberesan harta pailit, namun tetapi tidak terbatas pada informasi mengenai boedel pailit. Di dalam Undang-Undang No. 37 tahun 2004 tentang Kepailitan dan Penundaan Pembayaran Kewajiban Utang tidak diatur mengenai Kurator wajib memberitahukan kepada Pihak Ketiga mengenai harta pailit yang dimasukan ke dalam boedel pailit tetapi kurator wajib menyampaikan daftar boedel pailit ke Pengadilan sesuai dengan ketentuan Pasal 103 Undang-Undang No. 37 tahun 2004 tentang Kepailitan dan Penundaan Pembayaran Kewajiban Utang, agar dapat di lihat setiap orang.

Mengenai Lelang yang dilakukan oleh PT. OCBC NISP sudah sesuai dengan Undang-Undang No. 37 Tahun 2004 tentang Kepailitan dan Penundaan Pembayaran Kewajiban Utang. Berdasarkan Pasal 55 Ayat (1) Jo. Pasal 56 Ayat (1) Undang-Undang Kepailitan Pemegang Jaminan Hak Tanggungan diberikan hak exklusif untuk melakukan lelang terlebih dahulu atas Boedel Pailit (harta pailit) dalam jangka waktu 90 (Sembilan puluh) hari, sejak debitor Pailit dinyatakan pailit

Pasal 55 Ayat (1) Undang-Undang No. 37 Tahun 2004 tentang Kepailitan dan Penundaan Pembayaran Kewajiban Utang. 
(1) Dengan tetap memperhatikan ketentuan sebagaimana dimaksud dalam Pasal 56, Pasal 57, dan Pasal 58, setiap Kreditor pemegang gadai, jaminan fidusia, hak tanggungan, hipotek, atau hak agunan atas kebendaan lainnya, dapat mengeksekusi haknya seolah-olah tidak terjadi kepailitan.

Jo. Pasal 56 Ayat (1) Undang-Undang No. 37 Tahun 2004 tentang Kepailitan dan Penundaan Pembayaran Kewajiban Utang.

(2) Hak eksekusi Kreditor sebagaimana dimaksud dalam Pasal 55 ayat (1) dan hak pihak ketiga untuk menuntut hartanya yang berada dalam penguasaan Debitor Pailit atau Kurator, ditangguhkan untuk jangka waktu paling lama 90 (sembilan puluh) hari sejak tanggal putusan pernyataan pailit diucapkan.

Debitur Pailit adalah PT. Mega Graha International, Debitur Pailit telah mendapatkan pinjaman dari Bank OCBC NISP, Tbk, dengan memberikan beberapa jaminan yang salah satunya adalah SHGB No. 3505/Meruya atas nama The Hwie Gwan. Putusan Pernyataan Pailit atas PT. Mega Graha International (Debitor Pailit) diucapkan pada tanggal 23 Juli 2015, lalu PT. OCBC NISP, Tbk selaku kreditor separatis (kreditor pemegang hak tanggungan) melakukan lelang di 15 September 2015, masih dalam tenggang waktu 90 (Sembilan puluh) hari, sehingga pelaksanaan lelang yang dilakukan oleh PT. OCBC NISP atas jaminan hak tanggungan atas nama PT. Mega Graha International yang diberikan kepada PT. OCBC NISP, Tbk masih sesuai dengan peraturan perundang-undangan, seharusnya Kantor Lelang tetap melaksanakan lelang tersebut karena permohonan lelang yang diajukan oleh PT. OCBC NISP, Tbk masih dalam tenggang waktu 90 (Sembilan puluh) hari sesuai dengan ketentuan pasal 55 Ayat (1) Jo. Pasal 56 Ayat (1) Undang-Undang No. 37 Tahun 2004 tentang Kepailitan dan Penundaan Pembayaran Kewajiban Utang, yang mana pemegang jaminan hak tanggungan diberikan hak untuk melakukan eksekusi seolah-olah tidak terjadi kepailitan dalam jangka waktu 90 (Sembilan puluh hari).

Pelaksanaan lelang memiliki mekanisme tersendiri yaitu diatur dalam Undang-Undang No. 4 tahun 1996 tentang Hak Tanggungan tidak dapat dikaitkan 
dengan Undang-Undang No. 37 tahun 2004 tentang Kepailitan dan Penundaan Kewajiban Pembayaran Utang dikarenakan Undang-Undang tersebut hanya membahas mengenai kepailitan dan bagaimana aset harta debitur saja, tetapi untuk masalah lelangnya, bagaimana proses lelangnya, proses eksekusi dari harta hak tanggungan ini diatur dalam Undang-Undang No. 4 tahun 1996 tentang Hak Tanggungan. Selanjutnya Undang-Undang No. 37 pasal 56 ayat 1 tahun 2004 tentang Kepailitan dan Penundaan Kewajiban Pembayaran Utang mengatur kalau harta aset jaminan yang hartanya sudah dijaminkan sebenarnya perlindungannya 100\% milik kreditur bahkan dikatakan di Undang-Undang bahwa harus dianggap seolah-olah tidak ada pailit, oleh karena itu kreditur dikasih waktu untuk menjual aset tersebut dalam waktu 90 hari/ 3 bulan, kalau dalam waktu itu kreditur tidak bisa menjual aset itu maka harta itu masuk ke dalam harta boedel pailit, tetapi ada prioritas dahulu si kreditur, oleh karena harta tersebut masuk ke dalam harta boedel pailit bukan berarti kurator dapat seenaknya saja, tetap diprioritaskan kepada kreditur yang pemegang jaminan karena tidak menghilangkan status jaminannya dari masuknya harta jaminan ke dalam boedel pailit. Tidak menghilangkan hak dari si kreditur sebagai pemegang jaminan, masuknya harta/aset debitur dalam boedel pailit tidak menghilangkan hak dari kreditur sebagai pemegang jaminan karena kreditur disini merupakan kreditur seperatis.

Pelaksanaan lelang memiliki mekanisme tersendiri yaitu diatur dalam Undang-Undang No. 4 tahun 1996 tentang Hak Tanggungan tidak dapat dikaitkan dengan Undang-Undang No. 37 tahun 2004 tentang Kepailitan dan Penundaan Kewajiban Pembayaran Utang dikarenakan Undang-Undang tersebut hanya membahas mengenai kepailitan dan bagaimana aset harta debitur saja, tetapi untuk masalah lelangnya, bagaimana proses lelangnya, proses eksekusi dari harta hak tanggungan ini diatur dalam Undang-Undang No. 4 tahun 1996 tentang Hak Tanggungan. Selanjutnya Undang-Undang No. 37 pasal 56 ayat 1 tahun 2004 tentang Kepailitan dan Penundaan Kewajiban Pembayaran Utang mengatur kalau harta aset jaminan yang hartanya sudah dijaminkan sebenarnya perlindungannya 100\% milik kreditur bahkan dikatakan di Undang-Undang bahwa harus dianggap seolah-olah tidak ada pailit, oleh karena itu kreditur dikasih waktu untuk menjual 
aset tersebut dalam waktu 90 hari/ 3 bulan, kalau dalam waktu itu kreditur tidak bisa menjual aset itu maka harta itu masuk ke dalam harta boedel pailit, tetapi ada prioritas dahulu si kreditur, oleh karena harta tersebut masuk ke dalam harta boedel pailit bukan berarti kurator dapat seenaknya saja, tetap diprioritaskan kepada kreditur yang pemegang jaminan karena tidak menghilangkan status jaminannya dari masuknya harta jaminan ke dalam boedel pailit. Tidak menghilangkan hak dari si kreditur sebagai pemegang jaminan, masuknya harta/aset debitur dalam boedel pailit tidak menghilangkan hak dari kreditur sebagai pemegang jaminan karena kreditur disini merupakan kreditur seperatis.

Bahwa bukanlah kurator yang menentukan tapi Undang-Undang sendiri sudah membawa kapan harta itu masuk ke dalam harta boedel pailit, tidak otomatis ketika kurator menentukan aset itu masuk ke dalam harta boedel pailit maka akan langsung masuk ke dalam harta boedel pailit, karena ada mekanisme di Undang-Undang No. 4 tahun 1996 tentang Hak Tanggungan dan Undang-Undang No. 37 pasal 56 ayat 1 tahun 2004 tentang Kepailitan dan Penundaan Kewajiban Pembayaran Utang bahwa kreditur pemegang jaminan boleh menjual terlebih dahulu, itu yang dilindungi oleh Undang-Undang karena ia sebagai pemegang jaminan.

PT. OCBC NISP telah diberikan waktu untuk melelang setelah insolvensi (diberikan waktu selama 2 bulan untuk menjual) tetapi setelah lewat masa waktu 2 bulan itu di Undang-Undang No. 37 Tahun 2004 tentang Kepailitan dan Penundaan Kewajiban Pembayaran Utang diatur bahwa harus menyerahkan ke kurator untuk dijual dan dimasukan kedalam harta pailit. Kurator pun bergerak berdasarkan laporan keuangan, masuk ke harta pailit karena di laporan keuangan mereka aset itu termasuk sebagai aktiva tetap, waktu itu juga beliau telah konfirmasi kepada debiturnya dan terdapat harta tersebut didalam laporan keuangan tersebut. Dan kalau di pailitkan juga kita memerlukan verifikasi yang mana itu aset, mana tagihannya, dan mana piutangnya.

Mengenai aset jaminan termasuk harta Boedel Pailit, ya hal tersebut termasuk, aset jaminan itu kan bisa menjadi harta pailit ketika diserahkan ke kurator setelah lewat 2 bulan, maka dari itu harta pailit adalah harta yang setelah 
berakhirnya masa waktu bank untuk menjualnya. Tetapi kalau sudah terjual maka aset jaminan tersebut bukanlah merupakan harta pailit.

Kurator tidak mungkin dapat memasukan jaminan ke dalam harta Boedel Pailit secara sepihak, dan lagi pula didalam kasus ini tidak ada Beliau memasukan jaminan ke dalam harta Boedel Pailit secara sepihak, karena Beliau pasti menempelkan atau pempublikasikannya di dalam pengadilan serta daftar tagihan, kurator itu wajib untuk mengumumkan daftar harta Boedel Pailit dalam jangka waktu tertentu PT. OCBC NISP apabila keberatan dapat mengajukan keberatan, malah menurut Beliau aneh apabila kurator tidak mengumumkan atau mempublikasikannya di pengadilan, dan pengumuman tersebut sudah jelas juga tertera tanda tangan hakim pengawas, kurator, dan panitera.

Asas independen dan tidak memihak hanya pada kepentingan kreditur sendiri atau semata-mata untuk kepentingan debitur adalah asas yang dianut dalam tugas dan kewenangan.kurator. Para pihak dapat mengajukan penggantian kurator apabila kurator dalam menjalankan tugasnya tidak independen.

Dalam dunia praktik, tidak jarang pula terjadi ke salah pahaman yang terjadi antara Debitor dan Kreditor. Di dalam kasus ini, PT. OCBC NISP selaku Debitor menganggap PT. Mega Graha Internasional selaku Kreditor lalai, yang dimaksud lalai disini adalah PT. Mega Graha Internasional dianggap secara sepihak memasukan jaminan ke dalam harta Boedel Pailit, yang nyatanya Ronal M. Aritonang menyatakan telah ada masa waktu yang diberikan kepada PT. OCBC NISP untuk melelang jaminan tersebut, dan tidak kunjung dilelang. Pengumuman pemasukan harta Boedel Pailit tersebut juga telah diumumkan di Pengadian Negeri Jakarta Pusat.

Menurut Pasal 104 ayat 4 Undang-Undang No. 40 tahun 2007 tentang Perseroan Terbatas yang berbunyi:

“ Anggota Direksi tidak bertanggungjawab atas kepailitan Perseroan sebagaimana dimaksud pada ayat (2) apabila dapat membuktikan:

e. Kepailitan tersebut bukan karena kesalahan atau kelalaiannya;

f. Telah melakukan pengurusan dengan itikad baik, kehati-hatian, dan penuh tanggungjawab untuk kepentingan Perseroan dan sesuai dengan maksud dan tujuan Perseroan; 
g. Tidak mempunyai benturan kepentingan baik langsung maupun tidak langsung atas tindakan pengurusan yang dilakukan; dan

h. Telah mengambil tindakan untuk mencegah terjadinya kepailitan.” Dimana dapat diketahui bahwa The Hwie Gwan selaku Dikertur tidak pernah dengan secara sengaja melakukan tidakan seperti yang tertulis dalam poin a sampai dengan poin d di dalam Undang-Undang Pasal 104 ayat 4 UndangUndang No. 40 tahun 2007 tentang Perseroan Terbatas, maka dari itu apa bila terjadi kepailitan, The Hwie Gwan selaku Direktur tidak berhak bertanggung jawab atas kepailitan tersebut dan aset kepemilikan The Hwie Gwan tidak dapat dimasukan kedalam Boedel Pailit dikarenakan bukan atas nama Perseroan tersebut.

Bapak Ronal M. Aritonang berpendapat bahwa harta seseorang yang tidak pailit dapat dijadikan Boedel Pailit hal itu bersumber pada laporan keuangannya, maksudnya adalah yang menjaminkan hal tersebut adalah PT. nya dan bukan pribadinya yang menjaminkan, didalam hak tanggungan juga telah dikatakan bahwa melepaskan hak atas aset tersebut untuk menjadi jaminan PT. OCBC NISP. The Hwie Gwan selaku Direktur dan atas nama sebidang tanah beserta bangunan yang dijaminkan juga telah setuju bahwa tanah beserta bangunan yang terletak di Meruya untuk di masukan ke dalam harta Boedel Pailit. The Hwie Gwan juga secara jelas tidak mengakui tanah beserta bangunan tersebut sebagai harta pribadinya karena tanah beserta bangunannya tersebut adalah bukan milik pribadi melainkan milik gabungan dari beberapa pihak (yaitu 3 orang). Bahwa The Hwie Gwan beserta kedua pihak lainnya secara pribadi telah menandatangani aset tersebut untuk di jadikan jaminan PT. OCBC NISP, dengan menandatanganinya secara tidak langsung The Hwie Gwan sudah melepaskannya untuk dijadikan jaminan. ${ }^{52)}$

Jadi berdasarkan uraian tersebut diatas, penulis berpendapat bahwa penolakan terhadap gugutan yang diajukan oleh PT. OCBC NISP sudah betul adanya dikarenakan sudah terdapat bukti secara tertulis diantara pihak

${ }^{52)}$ Ronal M. Aritonang. Wawancara dengan Kuasa Hukum Kurator dari PT. Mega Graha Internasional, Kantor Bernard Nainggolan \& Partners , Jakarta 24 Juni 2019. 
Debitur dan Kreditur bahwa The Hwie Gwan beserta 2 pihak lainnya telah melepaskan haknya dan menyerahkan tanah beserta bangunannya yang terletak di Meruya untuk dijadikan jaminan atas PT. Mega Graha Internasional.

\section{Penutup}

\section{A. Kesimpulan}

Berdasarkan hasil uraian analisis mengenai permasalahan yang diteliti sebelumnya, penulis berkesimpulan bahwa penolakan pada putusan nomor 769 K/Pdt.Sus-Pailit/2016 sudah betul adanya, karena terdapat beberapa fakta yang penulis dapatkan ketika wawancara langsung dengan pihak kuasa kurator dari PT. Mega Graha Internasional, dimana tidak benar adanya kata sepihak dalam gugatan seperti yang dikatakan oleh PT. OCBC NISP, dikarenakan kurator dari PT. Mega Graha Internasional telah memasang pengumuman tentang pemasukan tanah beserta bangunan yang terletak di Meruya ke dalam harta Boedel Pailit, dan surat pernyataan tersebut juga telah ditanda tangani oleh beberapa pihak didalam pengadilan dan tidak mungkin pihak dari PT. OCBC NISP tidak melihat pengumuman tersebut.

Kemudian juga sudah terdapat percakapan antara pihak PT. Mega Graha Internasional dengan PT. OCBC NISP sebelumnya mengenai tanah beserta bangunan tersebut, dimana kedua belah pihak menemukan solusi untuk membuat perjanjian secara tertulis yang dilakukan antara The Hwie Gwan selaku direktur dan atas nama tanah beserta bangunan, 2 pihak lain yang juga sebagai pemilik tanah tersebut dan pihak PT. OCBC NISP yang berisikan pelepasan hak atau dengan kata lain menyerahkan tanah beserta bangunan atas nama The Hwie Gwan untuk dijadikan jaminan atas PT. Mega Graha Internasional. Penulis juga berpendapat bahwa harta pailit sudah lebih meluas dari sebelumnya, dimana pada faktanya putusan No. 769 K/Pdt.SusPailit/2016 telah menjadi yurisprudensi, maka dari itu harta pailit bisa berupa apa saja yang penting terdapat bukti pendukungnya dan terdapat verifikasi dari pihak-pihak lain. 


\section{B. Saran}

Berdasarkan penulisan diatas, penulis berpendapat bahwa seharusnya dan lebih baik pihak PT. Mega Graha Internasional untuk melakuan inbreng terlebih dahulu terhadap tanah beserta bangunan yang terletak di Meruya. Kemudian yang dimaksud inbreng adalah penyetoran modal yang dilakukan tidak dalam bentuk uang tunai, melainkan dalam bentuk barang atau harta, agar tidak terjadi kesalahpahaman diantara kedua belah pihak. Bagi para praktisi pailit di Indonesia agar lebih bisa mengedukasi masyarakat terutama terhadap pihak yang bergerak didalam bidang usaha, baik bank, perusahaan maupun pihak lainnya agar kedepannya memiliki perbekalan ilmu yang cukup untuk melakukan kegiatan usaha dan dapat mengatasi terjadinya kepailitan atau permasalahan mengenai harta Boedel Pailit dikemudian hari.

Bagi PT. OCBC NISP selaku kreditur untuk dapat lebih dapat mempertanggung jawabkan atas kata-kata sepihak yang diucapkan di dalam gugatan, dimana seharusnya PT. OCBC NISP tidak berhak mengatakan kata sepihak, dikarenakan sejak awal sudah terdapat perjanjian diantara PT. OCBC NISP dengan PT. Mega Graha Interasional mengenai penyerahan tanah serta bangunan di atasnya yang terletak di Meruya untuk dijadikan jaminan atas PT. Mega Graha Internasional. Karena menurut pasal 1313 Kitab Undangundang Hukum Perdata Indonesia, perjanjian pada hakikatnya memiliki arti yaitu adalah suatu peristiwa di mana seorang atau satu pihak berjanji kepada seorang atau pihak lain atau di mana dua orang atau dua pihak itu saling berjanji untuk melaksanakan suatu hal.

\section{Daftar Pustaka}

\section{A. Buku}

Ahmad, Muslich Wardi. Fiqh Muamalat. (Jakarta: Amzah, 2015).

Ali, Chidir. Badan Hukum. (Alumni, 1987).

Ali, H. Zainudin. Metode Penelitian Hukum. (Jakarta: Sinar Grafika, 2009). 
Fuady, Munir. Hukum Kontrak: Teori dan Teknik Penyusunan Kontrak. (Jakarta: Sinar Grafika, 2003).

Fuady, Munir. Hukum Pailit dalam Teori dan Praktek. (Bandung: PT. Citra Aditya Bakti, 2010).

Hartini, Rahayu. Penyelesaian Sengketa Kepailitan di Indonesia, Dualisme Kewenangan Pengadilan Niaga \& Lembaga Arbitrase, Cetakan Ke-1. (Jakarta: Kencana Prenada Media Group, 2009).

Kartika, Sari Ela dan Advendi Simangunsong, SH, MM. Hukum dalam Ekonomi. (Jakarta: Grasindo).

Marzuki, Peter Mahmud. Penelitian Hukum (Edisi Revisi). (Jakarta: Kencana Prenada Media Group, 2009).

Muhammad, Abdulkadir. Hukum Perusahaan Indonesia. (Bandung: Citra Aditya Bakti,2002).

Nating, Imran. Peranan dan Tanggung Jawab Kurator dalam Pengurusan dan Pemberesan Harta Pailit. (Jakarta: PT Raja Grafindo Persada, 2005).

ND, Mukti Fajar dan Yulianto Achmad. MH, Dualisme Penelitian Hukum Normatif \& Empiris. Cetakan ke-IV. (Yogyakarta: Pustaka Pelajar, 2017).

S. Sastrawidjaaja, Man. Hukum Kepailitan dan Penundaan Kewajiban Pembayaran Utang. (Bandung: Alumni, 2014).

Situmorang, Victor M. dan Hendri Soekarso. Pengantar Hukum Kepailitan Di Indonesia. (Jakarta: PT Rineka Cipta, 1994).

Soebani, Beni Ahmad. Metode Penelitian Hukum. Cetakan ke-1. (Bandung: Pustaka Setia, 2009).

Subhan, M. Hadi. Hukum Kepailitan "Prinsip, Norma, dan Praktik di Peradilan”. (Jakarta: Kencana, 2008).

Suryatin, R. Hukum Dagang I dan II. (Jakarta: Pradnya Paramita, 1983).

Sutedi, Adrian. Hukum Kepailitan. (Jakarta: Ghalia Indonesia, 2009). 


\section{B. Jurnal/ Makalah}

Putriyanti, Erma Defiana, et, all. "kajian Hukum tentang Penerapan pembuktian sederhana dalam perkara pailit", diakses pada tanggal 7 Januari 2019.

Ramadhani, Bravika Bunga, "Penyelesaian Utang Piutang Melalui Kepailitan (Studi Kasus Pada Putusan Mahkamah Agung Republik Indonesia Tentang P.T.Prudential Life Insurance)", Program Studi Magister Kenotariatan, Universitas Diponegoro Semarang 2009.

Siti, Anisah, "Studi Komparasi terhadap Perlindungan Kepentingan Kreditor dan Debitor dalam Hukum Kepailitan", dalam Jurnal Hukum No. Edisi khusus vol. 16 oktober 2009: hal. 30 - 50.

Sriwijiastuti, "Lembaga Pkpu Sebagai Sarana Restrukturisasi Utang Bagi Debitor Terhadap Para Kreditor (Studi Kasus Pada PT. Anugerah Tiara Sejahtera)", program studi magister kenotariatan, program pascasarjana, universitas diponegoro, semarang, 2010, Hal.21.

Wibowo T. Tunardy, "Pengertian Badan Hukum", dalam Jurnal Hukum 11 September 2012.

\section{Peraturan Perundang-undangan}

Indonesia. Undang-Undang Dasar Negara Republik Indonesia 1954.

Indonesia. Undang-Undang Nomor 37 Tahun 2004 Tentang Kepailitan dan Penundaan Kewajiban Pembayaran Utang.

Indonesia. Undang-Undang Republik Indonesia Nomor 40 Tahun 2007 Tentang Perseroan Terbatas.

\section{Kamus}

Purwadarminta, 1997, Kamus Besar Bahasa Indonesia, Balai Pustaka, Jakarta.

\section{E. Internet}


https://www.ocbcnisp.com/Groups/Tentang-OCBC-NISP/Brief-

History.aspx (Diakses 4 Januari 2019) 